\title{
KAJIAN HUKUM KEHARUSAN BAGI NOTARIS DAN PPAT YANG MERANGKAP JABATAN BERKEDUDUKAN DALAM SATU DAERAH ATAU WILAYAH KERJA
}

\author{
Raden Hamengku Aji Dewondaru, Umar Ma'ruf** \\ * Mahasiswa Program Magister (S2) Kenotariatan Fakultas Hukum UNISSULA, Semarang email: \\ spextre@gmail.com \\ Dosen Fakultas Hukum UNISSULA, Semarang
}

\begin{abstract}
View the establishment of notary formation and PPAT that have been set Based on their respective authorities, it appears that a notary can Concurrent PPAT as long as in one working area within the territory of office Notary Public. This is the author's interest to study about duplicate Position, because it does not close the possibility will happen Dual positions between Notary and PPAT which not one office but still One area of notary public. So this discourse needs to be studied in order to be able Known the possible impact that will appear.

The formulation of the problem in this research are: 1.) Why are there any provisions that require notary work area / region and PPAT in one area / work area? 2.) What are the consequences or sanctions faced by a notary who holds PPAT if it is not domiciled in one territory / Working Area and 3.) What is the action done by the Honorary Assembly if the notary concurrent with PPAT is not domiciled in the same work area. The method used in this research is the normative juridical approach, the type of normative legal research. The source of the data is the secondary data. Technique of collecting data with bibliography, method of analysis by using method of qualitative data analysis. Problems are analyzed with the theory of benefit and the theory of justice

Based on the result of this research, it can be concluded 1.) Reason requiring Regional / Working Areas of Notary and PPAT in One Region / Working Area is in accordance with the Law on Notary Position and Government Regulation Number 37 Year 1998 About PPAT Regulation. 2.) Result or sanction faced by a Notary who concurrently PPAT if not domiciled in one region / work area. Legal effect to Notary Deed, the deed is null and void or can be canceled. Notary deed may be canceled because if there is a lawsuit from the parties mentioned in the deed to cancel notary deed and Legal Effect on Notary's Office. 3.) Acts Conducted by Honorary Council If Notary Accepting PPAT Not Domiciled In The Same Working Area gives warning and witness or revocation of permit.
\end{abstract}

Keywords: Multiple Position, Region / Working Area, Notary and PPAT

\section{PENDAHULUAN}

Notaris adalah Profesi hukum yang cukup menjanjikan. Dan untuk menjadi seorang notaris mempunyai beberapa kompetensi khusus yang harus dipenuhi. Jadi seorang notaris tidak mungkin bisa melakukan praktik tanpa memiliki kemampuan yang memadai. Yang melatarbelakangi adalah Pendidikan di bidang Hukum. Sebelum menempuh Pendidikan Strata 2 hukum kenotariatan harus menyelesaikan pendidikan Strata 1 Ilmu Hukum terlebih dahulu. Pejabat umum yang berwenang dalam pembuatan akta otentik adalah Notaris. Hal tersebut telah diatur di dalam ketentuan Pasal 1 UU No. 2 Tahun 2014 tentang perubahan UU No.30 Tahun 2004 tentang Jabatan Notaris. Notaris dapat disebut juga sebagai seorang pejabat negara dan atau pejabat umum, Yang dimuat dalam Pasal 1 UU No. 2 Tahun 2014 tentang 
perubahan UU No.30 Tahun 2004 tentang Jabatan Notaris. Notaris adalah pejabat umum yang menjalankan beberapa tugas umum dari negara, dan di bidang hukum perdata pada khususnya. ${ }^{1}$

Notaris sebagai pejabat umum mempunyai wewenang lebih luas dibandingkan PPAT karena Notaris berwenang membuat akta otentik mengenai perjanjian, perbuatan, dan ketetapan yang diatur dalam undang-undang maupun permintaan para pihak selama tidak dikecualikan oleh pejabat lain berdasar undang-undang. Sedangkan PPAT hanya berwenang membuat 8 jenis akta peralihan dan pembebanan hak atas tanah sebagaimana ditegaskan dalam PMNA/Perkaban Nomor 3 Tahun 1997 dan PP Nomor 37 Tahun 1998.

Dikeluarkannya Peraturan Pemerintah PP Nomor 24 Tahun 2016 tentang Perubahan atas PP Nomor 3 Tahun 1998 tentang Peraturan Jabatan Pejabat Pembuat Akta Tanah maka sejumlah substansi baru dalam PP hampir mendekati substansi dari UU No. 30 Tahun 2004 jo UU No. 2 Tahun 2014 tentang Jabatan Notaris (JN), khususnya mengenai wilayah kerja PPAT.

Dalam praktiknya PPAT, sebagai pejabat umum yang berwenang dalam membuat akta otentik khusus yang berkaitan dengan akta pertanahan diragukan bahkan dikritisi selama ini eksistensi kedudukannya. Mengenai hal-hal yang menjadi penyebab keraguan dan kritik tersebut yaitu, yang pertama, tidak adanya suatu dasar hukum dalam bentuk Undangundang yang mengatur kedudukan PPAT sebagai pejabat umum. Yang selama ini Peraturan jabatan PPAT hanya diatur di dalam bentuk PP.

Yang kedua yaitu wewenang PPAT dibatasi hanya untuk pembuatan akta pertanahan dalam susunan informal selain dari bentuk blanko akta yang telah ditetapkan oleh Kepala BPN. Keterkaitan PPAT dalam pembuatan akta pertanahan melalui metode mengisi blanko akta yang telah disediakan oleh

\footnotetext{
${ }^{1}$ Yudha Pandu (ed.), 2009, Himpunan Peraturan Perundang-undangan Jabatan Notaris dan PPAT, Indonesia Legal Center Publishing, Jakarta, h.2
}

BPN dianggap mengurangi fundamen atas kedudukan PPAT sebagai pejabat umum itu sendiri. Seharusnya PPAT diberikan kewenangan yang sama dengan Notaris dalam pembuatan aktanya sendiri melalui ditegaskannya kedudukan PPAT sebagai pejabat umum dalam sejumlah peraturan perundang-undangan bukan sebaliknya mengisi blanko dalam pembuatan aktanya. Berdasarkan uraian permasalahan di atas, maka akan dianalisis eksistensi jabatan PPAT sebagai pejabat umum yang mempunyai hak untuk menerbitkan akta otentik. Notaris dilarang untuk merangkap jabatan di luar wilayah jabatan notaris, hal tersebut telah ditegaskan pada Pasal 17 huruf g. Dan bila terjadi pelanggaran akan dikenai sanksi administratif dari MPN secara berjenjang sesuai Pasal 85 UUJN Notaris, yang sebelumnya diberi keluasan untuk dapat membela diri dimulai dari Majelis Pengawas Daerah (yang selanjutnya disingkat MPD), lalu naik ke tingkat Majelis Pengawas Wilayah (yang selanjutnya disingkat MPW), lalu naik lagi ketingkat Majelis Pengawas Pusat (yang selanjutnya disingkat MPP) lalu untuk putusan akhirnya atas usulan MPP akan diberikan sanksi pemberhentian secara tidak hormat oleh Menteri Hukum dan HAM Republik Indonesia sesuai dengan Perundangan yang berlaku di Indonesia.

Berdasarkan kewenangan masing-masing, seorang notaris bisa merangkap PPAT dengan syarat masih dalam satu wilayah kerja di dalam wilayah jabatan notaris sesuai penetapan formasi notaris dan PPAT. Penulis tertarik untuk meneliti perihal banyaknya dampak yang akan muncul terhadap rangkap jabatan, karena terdapat banyak kejadian Notaris merangkap menjadi PPAT yang berada tidak satu kantor akan tetapi masih dalam satu wilayah jabatan notaris.

Hal tersebut diatas yang membuat Penulis tertarik untuk meneliti perihal Kajian Hukum Keharusan Bagi Notaris dan PPAT Yang Merangkap Jabatan Berkedudukan Dalam Satu Daerah Atau Wilayah Kerja. 


\section{METODE PENELITIAN}

Penelitian ini menggunakan metode pendekatan yuridis normatif, yaitu suatu penelitian yang deduktif dimulai analisa terhadap pasal-pasal dalam peraturan perundang-undangan yang mengatur terhadap permasalahan yang ada. Penelitian hukum secara yuridis maksudnya penelitian yang mengacu pada studi kepustakaan yang ada ataupun terhadap data sekunder yang digunakan. Dalam penulisan ini penulis menggunakan analisa data secara kualitatif yaitu suatu cara penelitian yang menghasilkan data secara deskriptif.

\section{hASIL PENELITIAN DAN PEMBAHASAN}

\section{Ketentuan Yang Mengharuskan Daerah/ Wilayah Kerja Notaris Dan PPAT Dalam Satu Wilayah/Daerah Kerja}

Notaris dalam melaksanakan jabatannya pada satu kantor atau di wilayah kedudukan yang telah ditentukan. Pada kenyataannya notaris banyak melakukan pelanggaran yang antara lain terdapat notaris membuat akta di luar dari wilayah kedudukannya. Hal tersebut tidak terlepas dari kebutuhan notaris tersebut. Sebab terjadi banyak persaingan yang ketat dan terdapat pelanggan berkeinginan untuk dibuatkan sebuah akta di daerah tempat tinggalnya. Akta otentik yang dibuat di luar wilayah kedudukanya secara terusmenerus dan akta yang dibuat di luar wilayah jabatan seorang notaris, dan sanksi hukum yang diberikan pada notaris yang terbukti melanggar ketentuan mengenai wilayah kedudukan dan wilayah jabatan notaris berkaitan dengan pembuatan akta oleh seorang notaris di luar wilayah kedudukanya secara terusmenerus tersebut dilarang sebab tidak sesuai dengan pasal 17 huruf a, pasal 18, dan 19 Undangundang jabatan notaris. ${ }^{1}$

\footnotetext{
${ }^{1}$ Siregar Soritua Halomoan, Pembuatan Akta Di Luar tempat Kedudukan dan Diluar Wilayah Notaris, Airlangga University Library , Surabaya.2011.hal V
}

Pelaksanaan tugas jabatan notaris diluar wilayah jabatanya tidak diperbolehkan atau merupakan sebuah larangan bagi notaris. Artinya seoarang notaris dilarang melaksanakan tugas jabatanya diluar wilayah provinsi dimana ia bertempat kedudukan. $\mathrm{Di}$ dalam penjelasan pasa disbeutkan bahwa maksud dan laragan ini untuk memberikan kepastian hukum kepada masyarakat dan sekaligus mencegah persaingan tidak sehat atar notaris dalam menjalankan jabatanya. ${ }^{2}$

Secara filosofis munculnya UndangUndang Jabatan Notaris (UUJN) No.30 Tahun 2004 diundangkan di Jakarta, tanggal 6 Oktober 2004, seperti ditempatkan pada Lembaran Negara RI Tahun 2004 No. 117 yang terdiri atas 13 Bab dan 92 Pasal hal ini mempertegas peran pokok notaris sebagai seorang pejabat umum yang memberi kepastian hukum dengan cara membuat akta otentik. Landasan filosofis lahirnya UndangUndang Jabatan Notaris Nomor 30 Tahun 2004 adalah terwujudnya jaminan kepastian hukum, ketertiban dan perlindungan hukum yang berintikan kebenaran, dan keadilan. Melalui akta yang dibuatnya, Notaris harus dapat memberikan kepastian hukum kepada masyarakat pengguna jasa Notaris. ${ }^{5}$

\section{Akibat Atau Sanksi Yang Dihadapi Oleh Notaris Yang Merangkap PPAT jika tidak berkedudukan dalam satu wilayah/ daerah kerja}

1. Akibat Hukum Terhadap Akta Notaris

Akta yang dibuat notaris mempunyai kekuatan hukum sempurna, karena dibuat dalam bentuk akta autentik, dalam tataran hukum Kenotariatan yang benar mengenai Akta Notaris dan Notaris. Dalam pembuatan akta autentik hal yang perlu diperhatikan adalah walaupun semua syarat dan unsur-

2 Hartoyo, Analisis Terhadap Pelaksanaan Tugas dan Jabatan Notaris Di Luar Tempat Kedudukan, Fakultas Hukum Universitas Gadjah Mada, Yogyakarta, 2012, hal113

5 H. Salim HS. \& H. Abdullah, 2007, Perancangan Kontrak dan MOU, Sinar Grafika, Jakarta, hlm. 101-102 
unsur akta autentik telah terpenuhi, suatu akta autentik dapat dikatakan autentik jika akta tersebut sepanjang tidak ada orang atau pihak yang mempermasalahkan keautentikan akta tersebut dan seorang itu tidak dapat membuktikan bahwa akta tersebut cacat, maka Akta itu tetap dianggap berasal dari pejabat yang berwenang dan sah demi hukum. Sebaliknya jika akta tersebut dapat dibuktikan oleh pihak lain, ternyata cacat, maka demi hukum, akta tersebut adalah batal demi hukum atau dapat dibatalkan. Akta notaris dapat dibatalkan karena jika ada gugatan dari para pihak yang tersebut dalam akta untuk membatalkan akta notaris. Pembatalan Akta Notaris hanya dapat dilakukan oleh para pihak itu sendiri. ${ }^{3}$

Dalam setiap kegiatan yang dilakukan notaris dapat mempertanggungjawabkan atas kesalahan dan kelalaian yang dilakukanya dalam pelaksanaan tugas dan jabatanya notaris tidak bertanggungjawab pada isi dari akta yang dibuat dihadapanya, tanggungjawab notaris hanya terletak pada bentuk formal suatu akta otentik sebagaimana dicantumkan dalam Undangundang.

Ruang lingkup pertanggung jawabaan mencakup keaslian materiil atas akta yang dbuatnya. Kelalaian dan kesalahan isi dari akta yang dibuatnya diluar dari tanggungjawab notaris, tanggungjawab notaris hanya dalam bentuk formil akta otentik sesuai dengan yang telah ditentukan oleh Undang-undang.

Dalam keputusan diatas ketidakotentikan akta notaris yang telah dibuat oleh notaris maka dalam pembuatanya terjadi kebatalan. Herlien Budiono berpendapat apabila Undang-undang menerangkan tidak adanya akibat hukum, maka diterangkan dengan istilah batal dan tidak berharga (Pasal 879 KUH Perdata) atau tidak memiliki kekuatan hukum (Pasal 1335 KUH Perdata). Pemakaian istilah ini seringkali

\footnotetext{
${ }^{3}$ Ibid hal.22
}

membingungkan karna istilah yang sama terkadang digunakan dalam pengertian yang berbeda dalam batal demi hukum atau bisa dibatalkan. Pada pasal $1446 \mathrm{KUH}$ Perdata dan seterusnya untuk menyatakan batalnya suatu perbuatan hukum kita temukan istilah-istilah "batal demi hukum", "membatalkanya" ( Pasal 1449 KUH Perdata), menuntut pembatalan (Pasal 1450 KUH Perdata), "Pernyataan batal" (Pasal 1451-1452 KUH Perdata), "gugur" (Pasal 1545 KUH Perdata), dan gugur demi hukum (Pasal 1553 KUH Perdata) ${ }^{4}$

2. Akibat Hukum Terhadap Jabatan Notaris

Notaris sebagai pejabat umum yang berarti kepada notaris diberikan dan dilengkapi dengan kewenangan atau kekuasaan umum yang menyangkut publik openbaar gezag. ${ }^{5}$ Dalam memberikan pelayanan kepentingan umum (public service) dalam arti bidang pelayanan pembuatan kata dan tugas-tugas lain yang dibebankan kepada notaris, yang melekat pada predikat sebagai pejabat umum dalam ruang lingkup tugas dan kewenangan notaris. $^{6}$

Dalam menjalankan jabatanya sebagai pejabat umum notaris di berikan kewenangan kepada negara untuk mengerjakan sebuah akta otentik, lalu dalam melaksanakan tugasnya seorang notaris wajib sesuai dengan jalur yang ditetapkan, bertanggung jawab dan kewajiban yang telah dinyatakan dalam Peraturan Jabatan Notaris serta Kode Etik Notaris. Kewajiban seorang notaris adalah suatu kewajiban yang harus dilaksanakan, jika tidak dilaksanakan atau dilanggar maka Notaris tersebut akan di beri sanksi sebagaimana disebutkan dalam Pasal 84 Undang-undang Jabatan Notaris. Adapun

4 Ibid.

${ }^{5}$ R. Soegondo Notodisoerjo. Hukum Notariat di Indonesia suatu Penjelasan, Raja Grafindo Persada, Jakarta, 1993, hal. 44.

${ }^{6}$ Paulus Efendi Lotulung, Perlindungan Hukum Bagi Notaris, Makalah dalam rangka Kogres Ikatan Notaris Indonesia, Bandung, Januari.2003. 
kewajiban notaris sudah tercantum dalam Pasal 16 UUJN.

Dalam menjalankan kewenangan sebagaimana telah diatur dalam Pasal 15 UUJN, pemerintah juga mengatur larangan jabatan notaris dalam menjalankan kewenanganya. Hal ini jelas tertuang dalam Pasal 17 Undang-Undang Nomor 30 Tahun 2004 tentang Jabatan Notaris

3. Tindakan Yang Dilakukan Oleh Majelis Kehormatan Apabila Notaris Merangkap PPAT Tidak Berkedudukan Di Wilayah Kerja Yang Sama

Menteri melaksanakan pembinaan dan pengawasan terhadap pelaksanaan tugas PPAT. Pembinaan dan pengawasan tersebut dilakukan dengan :

a. Pelaksanaan peraturan mengenai kePPAT-an sebagai pelaksanaan PP Nomor 37 Tahun 1998;

b. Pelaksanaan peraturan dan ketentuan teknis tentang penerapan tugas seorang PPAT;

c. Pemberitahuan tentang kebijaksanaan maupun peraturan pertanahan dan petunjuk teknis kepada seorang PPAT;

d. Pemeriksaan tentang pelaksanaan kewajiban-kewajiban PPAT;

e. penggunaan denda administratif kepada PPAT yang telah melakukan pelanggaran dan tidak melaksanakan kewajibanya.

Dalam rangka pembinaan dan pengawasan pelaksanaan tugas PPAT, Kantor Pusat Badan Pertanahan Nasional :

a. Memberikan petunjuk teknis tentang cara melaksanakan tugas jabatan PPAT;

b. Memberitahu tentang kebijaksanaan dan peraturan pertanahan dan petunjuk teknis melaksanakan tugas jabatan PPAT yang telah ditentukan oleh pejabat yang memiliki wewenang menurut peraturan perundang undangan yang masih berlaku.

Dalam rangka pembinaan dan pengawasan PPAT, Kepala Kantor Wilayah : a. Memberitahu tentang kebijaksanaan dan peraturan pertanahan dan petunjuk teknis melaksanakan tugas jabatan PPAT yang telah ditentukan oleh pejabat yang memiliki wewenang menurut peraturan perundang undangan yang masih berlaku.

b. Melaksanakan fungsinya denda administratif kepada PPAT yang telah melakukan pelanggaran dan tidak melaksanakan kewajibanya.

Dalam rangka pembinaan dan pengawasan PPAT, Kepala Kantor Pertanahan :

a. Memberitahu tentang kebijaksanaan dan peraturan pertanahan dan petunjuk teknis melaksanakan tugas jabatan PPAT yang telah ditentukan oleh pejabat yang memiliki wewenang menurut peraturan perundang undangan yang masih berlaku koordinasi Kepala Kantor Wilayah;

b. Melaksanakan fungsinya denda administratif kepada PPAT yang telah melakukan pelanggaran dan tidak melaksanakan kewajibanya sesuai dengan ketentuan yang ada

c. mengecek akta PPAT dalam rangka pendaftaran peralihan atau pembebanan hak atas tanah yang bersangkutan dan memberitahukan alasannya secara tertulis kepada PPAT yang bersangkutan apabila akta tersebut tidak memenuhi syarat sebagai dasar pendaftaran peralihan atau pembebanan hak;

d. melaksanakan pemeriksaan tentang pelaksanaan kewajiban operasional PPAT.

\section{KESIMPULAN}

Dari uraian yang telah peneliti paparkan pada bab-bab sebelumnya maka peneliti dapat mengambil kesimpulan tesis sebagai berikut :

1. Ketentuan Yang Mengharuskan Daerah/ Wilayah Kerja Notaris Dan PPAT Dalam Satu Wilayah/Daerah Kerja yaitu sesuai dengan Undang-Undang tentang Jabatan Notaris 
dan Peraturan Pemerintah Republik Indonesia Nomor 37 Tahun 1998 Tentang Peraturan Jabatan PPAT.

2. Akibat Atau Sanksi Yang Dihadapi Oleh Notaris Yang Merangkap PPAT jika tidak berkedudukan dalam satu wilayah/ daerah kerja.

a. Akibat Hukum Terhadap Akta Notaris Akta tersebut adalah batal demi hukum atau dapat dibatalkan. Akta notaris dapat dibatalkan karena jika ada gugatan dari para pihak yang tersebut dalam akta untuk membatalkan akta notaris.

b. Akibat Hukum Terhadap Jabatan Notaris Jika notaris terbukti melanggar UUJN mendapatkan sanksi berupa sanksi administratif yaitu pengenaan uang paksa oleh pemerintah. Pemberian sanksi pengenaan uang paksa oleh pemerintah ditujukan untuk menambah hukuman yang pasti, disamping denda yang telah disebutkan dengan tegas di dalam peraturan perundang-undangan yang bersangkutan.

c. Tindakan Yang Dilakukan Oleh Majelis Kehormatan Apabila Notaris Merangkap PPAT Tidak Berkedudukan Di Wilayah Kerja Yang Sama memberikan teguran dan saksi atau pencabutan izin.

\section{SARAN}

1. Kepada Notaris / PPAT yang mengalami permasalahan sebagaimana tersebut diatas, disarankan untuk tidak membuat Akta Notaris maupun Akta PPAT dalam permasalahan beda tempat kedudukan dan wilayah jabatan.
2. Berkenaan dengan tujuan yang hendak dicapai dengan adanya Majelis Pengawas dan Organisasi Profesi yaitu meningkatkan profesionalisme dan kualitas kerja Notaris / PPAT sehingga dapat memberikan jaminan kepastian dan perlindungan hukum bagi pengguna jasa Notaris / PPAT dan masyarakat luas diperlukan juga kerjasama dan koordinasi dari Notaris / PPAT yang bersangkutan dalam hal melaporkan kendalah-kendala, permasalahan permasalahan yang sedang dihadapi yang bersangkutan.

\section{DAFTAR PUSTAKA}

Abdul Ghofur Anshori, Lembaga Kenotariatan Indonesia Perspektif Hukum dan Etika, (Yogyakarta: UII Press, 2009)

Hartoyo, Analisis Terhadap Pelaksanaan Tugas dan Jabatan Notaris Di Luar Tempat Kedudukan, Fakultas Hukum Universitas Gadjah Mada, Yogyakarta, 2012

Paulus Efendi Lotulung, Perlindungan Hukum Bagi Notaris, Makalah dalam rangka Kogres Ikatan Notaris Indonesia, Bandung, Januari.2003.

R. Soegondo Notodisoerjo. Hukum Notariat di Indonesia suatu Penjelasan, Raja Grafindo Persada, Jakarta, 1993

Salim HS. \& H. Abdullah, 2007, Perancangan Kontrak dan MOU, Sinar Grafika, Jakarta

Siregar Soritua Halomoan, Pembuatan Akta Di Luar tempat Kedudukan dan Diluar Wilayah Notaris, Airlangga University Library, Surabaya.2011

Yudha Pandu (ed.), 2009, Himpunan Peraturan Perundang-undangan Jabatan Notaris dan $P P A T$, Indonesia Legal Center Publishing, Jakarta 